\title{
2
}

\section{Has Australia's administrative heritage maintained a culture of agrarian dependency?}

\author{
Ian Gray
}

\begin{abstract}
The Australian Federation brought together colonies that had developed centralised administrative systems over an equally centralised pattern of settlement. Rural society was developed under agrarian ideals that differentiated country from city in social and political as well as cultural terms. While similar ideals were held in Europe and North America, the colonial administration of such important instruments of rural development as railways and local government left Australian rural areas in a condition of dependency that the regionalist traditions and stronger local governments of Europe and North America might not have permitted. The expression of 'country-mindedness' and the establishment of the almost unique National (formerly Country) Party alongside administrative tradition have helped to preserve a climate in which appeals to administrative apparatuses firmly based in state capitals have been the principal recognised means of solving local problems. Rural culture as well as the structural conditions of dependency could have blinkered community perception of possible means of local advancement by way of self-governance, other than where business opportunities are presented in familiar industries. Much has been said and written about rural communities being blinkered to economic opportunity, but despite some penetrating analysis, conflation of economic and political dimensions remains a problem. Criticism of rural communities for being blinkered and passive is paradoxical in a cultural context in which self-reliance at the individual level is held as an important ideal and farmer organisations have been very active. After examining some literature, this chapter illustrates these points with brief references to the history of grain handling, irrigation, natural resource management and railways in New South Wales, from their establishment through to the restructuring that occurred during and since the 1990s. In concluding, this chapter suggests appropriate dimensions for cultural research and analysis.
\end{abstract}




\section{Introduction}

Any comparison between Australia and Europe - most obviously, the United Kingdom - could not escape the fundamental point that Australia was colonised while industrialising Europe was colonising. Colonial settlement grew relatively rapidly during the late eighteenth century and, although much growth occurred inland, each colony was administered from a capital city located on the coast with very little delegation to local communities. The colonial relationship is still apparent in each state's administrative hierarchy and the federal system, making reasonable overseas comparisons in governance enduringly difficult, even though neo-liberalism and parallel new models of localising and regionalising governance have been very influential in Australia and Europe.

This chapter focuses on a cultural element that is associated with this centralised administrative system. The structure of the metropolitan-regional system in Australia has been analysed extensively, and likewise rural cultures, but the connection with governance is not made so often. There has long been a broad interpretation of the rural Australian world view, or 'community self-concept' (Curry 2000:694, drawing on Clifford Geertz), available alongside the political economy of regional development and disadvantage (see Gray and Lawrence 2001). Much has been written about farm cultures and their significance for farm practice and environments (such as Vanclay et al. 1998). The rural community studies literature has explored town culture in relation to ruralism (see, for example, Gray 1991). The history of the National Party, 'country-mindedness' (Aitkin 1985) and new state movements have shown a radical, sometimes almost revolutionary, element in rural culture. Though waning at times, this element has been significant historically, but in the research literature it has generally not been tied to current problems of economic and social restructuring. There is a case for making this connection and reinterpreting metropolitan-regional relations accordingly. The case is made below with an eye to administrative structures and the prospects for regionalisation.

\section{The administrative geography of Australian rural development}

Unlike the comparable countries of North America, and other than the national capital created after federation, inland cities that could rival the capitals did not arise in Australia. Inland Australia has possessed relatively little secondary industry or commercial administration. No inland city has been able to rival the administrative and commercial strengths of the coastal state capitals. A by-product of this early dominance was the capacity of each colony to ignore the others, except to attempt to ensure that neighbouring colonies did not siphon trade. This rivalry substantially affected the pattern of settlement and administrative relations among the state capitals. 
It is, however, possible to identify sub-state regions in terms of economic, demographic and environmental characteristics to which the state boundaries have little or no relevance. The states are sometimes said to be unnecessary historical anomalies, hindering rational planning and development (see, for example, Soorley 2004). Nevertheless, the states and particularly their capitals dominate Australia's political and economic geography. Despite a significant drift of population to dispersed coastal towns where tourism and service industries are growing, the state capitals remain demographically dominant and are likely to remain so. For example, Sydney is projected to show about 70 per cent of the population growth of New South Wales in 2031. Coastal areas are expected to grow the most rapidly in percentage terms, while inland areas are expected to continue to lose population (Transport and Population Data Centre 2004).

This relationship between country and city has a political element. It has provided the basis of an important dimension of Australian politics with the development of a continuing national political party, which has attempted to represent the views of rural residents (see Costar and Woodward 1985). It was founded on the ideology of country-mindedness: belief in the distinctiveness, value and legitimacy of rural interests founded on agrarian values and counterpoised with city interests. The city-country relationship is also expressed in state-local government relations. Rural local government is a product of colonial governments' attempts to force local people to take responsibility for some of the costs of development. From the outset, rural communities had to seek favours from colonial governments for development to occur, and leaders emerged around the need to promote local interests (Chapman and Wood 1984). From the 1850s, the colonies permitted incorporation of local councils having taxation (rating) capability. Many local government areas have relatively small populations and hence have very limited revenue-raising capacity. The governments of New South Wales and Tasmania found it necessary to enforce incorporation in many areas. Chapman and Wood (1984:39) mention that in the mid 1980s, just more than half of all local authorities had populations smaller than 5000 people, despite some recent amalgamations of small rural councils. Local councils have generally been reluctant to extend their responsibilities by increasing their taxation revenue, and have been reluctant to combine with other councils to form larger organisations. Local government continues to exist only under the authority of state government legislation and administration. With the likely exception of the one very large council, that of Brisbane City, Australian local government is not capable of accepting sufficient effective responsibility to become a likely vehicle for regionalisation, decentralisation and certainly not devolution.

The Australian tradition of local government is one of small and subservient institutions. State governments remain entrenched in the overwhelmingly 
populous and economically strong state capitals. Although appearing to attempt decentralisation from time to time by transferring departments or parts of them to regional cities, and sometimes later transferring them back again, the hierarchy of state administration extends outwards and downwards, with some variation among the states, from the capitals, as it has always done. Debate about the size and strength of Australian local government has focused on economic efficiency arguments rather than power and devolution (Dollery and Crase 2006). Where devolution has occurred it has tended to be functions and responsibilities that are devolved rather than power - a situation leading Dollery and Crase to support the view that Australian local government is financially unsustainable.

\section{Dependency, governance and rural restructuring}

The culture of rural local government, and rural communities more broadly, has been one in which subservience to the state government is understood - in the sense that it is taken for granted as well as in the sense of familiarity. Debates about rural restructuring among researchers and practitioners, including small-town 'revivalists' (Gray 2005a) who seek to reverse the detrimental economic and social effects of change, illuminate this culture. The researchers do so as they implicitly propose that exerting influence over state governments either amounts to expression of autonomy or at least indicates something other than an absolute power relationship as rural interests are 'translated' (see Herbert-Cheshire 2003) rather than exerted independently. The practitioners are similar as they identify the culture to be changed as one of dependency identifiable among individuals and expressed as the absence of entrepreneurialism. Both groups - the researchers and the activists - are at least partly correct in what they see and what they conclude. The problem is that they tend to be a little myopic. Moreover, they conflate political powerlessness and economic passivity.

Those who perceive a power structure see it in terms of struggle against central government, while those who take an apolitical view see business failure amid opportunity. Among those who acknowledge local-central power relations, Herbert-Cheshire (2003:255) identifies previous research that shows 'local people to negotiate, challenge and ultimately transform rural policy' but not create policy for themselves as a truly autonomous organisation might be expected to do. In her own research, Herbert-Cheshire uses actor network theory to circumvent conceptualisation of power in terms of either passivity or resistance and admits the possibility that those in power might be displaced by the translation of interests towards something more consistent with those of the formerly powerless. Herbert-Cheshire presents a scenario in which local people are able to persuade a state government to modify and reverse its decisions to terminate a train service and close a courthouse. She presents another scenario 
through which local people persuade a Commonwealth Government department to change an industry-support funding formula.

While these cases certainly illustrate 'translation' and validate the rejection of absolute conceptualisations of power, it is notable that in neither instance did a community act without reference to a central government. They apparently did not, for example, attempt to recreate the courthouse for themselves, start their own freight service or establish their own sources for industry support. In some parallel analysis, Herbert-Cheshire and Higgins (2004) contrast small rural communities in terms of the response to decline as occurring in a single dimension: one community heeding the neo-liberal dictum of the revivalists and redefining itself as entrepreneurial while the other remains reactive to government. They contrast entrepreneurialism with continuing political weakness rather than, as they might, distilling two dimensions: economic passivity-activity and political subservience-autonomy. An economically active, entrepreneurial community can remain dependent, while it is conceivable, though admittedly unlikely given the structure and culture of local government, that an economically passive community could have some autonomy.

In Herbert-Cheshire's comparison, the apparently economically successful community ceased or reduced its level of protest to government while the unsuccessful case chose to continue traditional anti-government protest, contributing further to its own illegitimacy in the neo-liberal ideological framework. The latter also did what we might predict given the tradition of political/administrative subservience. What, however, of the former entrepreneurial and apparently successful community? Herbert-Cheshire and Higgins attributed the success to the enrolment of outside expertise, which, under neo-liberal logic, was able to change the attitude of local people away from dependency towards entrepreneurialism. They use success in obtaining central government grant funding as an indicator of reform and renewal, as well as some business development. As Herbert-Cheshire and Higgins note, however, this success has not gone so far as reversing population decline and the problems of agricultural industries. It has more to do with the ability of neo-liberal rhetoric to define success and, I would add, its capacity to distract attention from the political subservience-autonomy dimension.

In political terms, the successful community acted neither independently nor in concert with other communities. It might have changed its economic world view, but only at the prompting of central government and apparently only in terms of its perception of local business. This observation prompts, at very least, some critical questioning of whether or not this 'success', which Herbert-Cheshire and Higgins show to be at least questionable, will prove to be in the community's long-term interests. It also prompts questioning of this world view in which community action is seen only as entrepreneurialism to the denigration of political 
action, or the viewing of it as such becomes legitimate. From the perspective of the history of Australian administrative tradition, this looks like the untranslated (Herbert-Cheshire 2004) exercise of metropolitan power. For present purposes, the important point is that although an entrepreneurial culture seems to have emerged or an old one has been strengthened, the relationship with government has not changed.

Is there any evidence of the relationship changing? Local government has been changed by amalgamation of small councils into large ones, most dramatically in Victoria. O'Toole and Burdess (2004) portrayed this as the emergence of a new mode of governance because a variety of community organisations grew in Victoria in response to local government amalgamations and the consequent loss by some local communities of their own council. Changes to local government have been and are being considered and implemented in other states, almost always involving amalgamation. There is no evidence that amalgamations create politically stronger institutions in their relations with central government. O'Toole and Burdess (2004) discuss change in terms of the creation of community organisations that react to enlarged local government in the familiar way-just as local government is reactive to state government.

Of course it is easy to make accusations of passivity from a distance in time and space, with no knowledge of the circumstances other than the communities being small and suffering from restructuring. It is also absurd to expect a small community to establish its own legal system or development funding independently of central government. It is, however, reasonable to surmise, for purposes of further investigation, that the traditional world view of the community members would not have prompted them to consider non-government (as Herbert-Cheshire and Higgins suggest) or locally governed alternatives. It is hard to see success in obtaining central government funding as a sure step towards autonomy. Very many small rural communities have organised themselves to retain or develop local industries (Cocklin and Dibden 2005). Perhaps the best type, or certainly best-known example, of a non-government alternative is that promoted by the Bendigo Bank. The Bendigo Bank works in partnership with local people to re-establish branches in small towns after the metropolitan banks have withdrawn. While only partially localised, the rise of Bendigo Bank branches in small towns does illustrate local participation in development without central government involvement. It hints at what might be done with greater cooperation and resource pooling among rural communities.

This view has a point of consistency with those who advocate community self-help and entrepreneurship: 'revivalists', as apparent in Kenyon and Black (2001) and Stoeckel (1998). From this perspective, the correct response to neo-liberalism and restructuring is the development of local business and industry of the kind that Herbert-Cheshire and Higgins identify in their successful case. 
This does not contradict the power relationship models, but it does ignore the history of development through which rural localities have been created as political dependencies of the metropolitan cities. It is frequently and reasonably criticised for promoting or at least risking victim blaming. Nevertheless, it is worth noting for the way it points towards a culture in which local self-governance does not come to mind as a response to economic and social decline. The existence of work such as Kenyon and Black's and exhortations like that of Stoeckel's implies a cultural problem, though not necessarily one that can be solved at the individual level, and not without reference to the development of rural local cultures in a political relationship with metropolitan Australia.

\section{Radical rural governance}

Locally governed alternatives are even more difficult to imagine given the status of local government. What, then, of the National Party? Has it operated in the political dimension that the revivalists ignore? The answer must be yes, but it operates in the same governance framework as it has sought to change relations within the political dimension rather than change the institutions of it. There is, however, a streak of radicalism in Australia's rural history. The proponents of new states apparently have had no difficulty in imagining drastic institutional change towards more regionalised governance.

The creation of new states has been a popular idea in many regional areas. It effectively means secession from existing states, but it is specifically allowed under the Australian Constitution if certain requirements are met. The new-state movement has roots in the creation of existing states, but has progressed no further despite the idea still retaining considerable support in Queensland and New South Wales at least. The idea that regional government should replace the states is also relatively popular, and not just in the rural areas that have been the wellsprings of new-state movements (Brown et al. 2006). While country-mindedness has promoted a rural-based political party, provided foundations for new-state movements in rural areas and generally been consistent with agrarian ideals of self-reliance, it has not helped to strengthen the only form of government residing in rural areas: local government. Nor has it successfully prompted effective agitation for reform of the federal system towards regionalisation.

Australia faces a governance dilemma: there is popular support for regionalisation at the same time as the states are losing influence to the Commonwealth, but local government does not currently provide a platform for devolution. The significance of the problem grows a little when trends towards 'new local governance' elsewhere, particularly in the United Kingdom, are considered. Here we see promotion of the idea of devolution alongside improvements in local governance (Stoker 2004). This comes amid the ever-present evidence that 
bottom-up, local initiative provides the best platform for promoting or ameliorating change and its effects and that central control can be unnecessary and undesirable (for a British environmental example, see Hinshelwood 2001). The significance of any change for the better in local governance has, however, been vigorously questioned (Bonney 2004). Some change to rural local governance, towards more participatory models, has been noted in Australia, but some of the old structures are persistent (Pini 2006). Moreover, it is hard to imagine 'new localism' taking hold in Australia: no Australian local council, with the possible exception of Brisbane City, has anything like the capacity to improve its environment as some of the big British cities have done. The debate in Australia remains focused on amalgamations of very small councils into slightly larger ones.

Research on rural local government has shown that the legitimacy of rural elected councillors rests on their ability to defend the interests of the locality, frequently against what are seen to be threats from central government, and initiatives that could conceivably bring rate increases are resisted (Gray 1991). The amalgamation of councils and the application of new management techniques, such as competitive tendering, have partially redefined local government, but nothing appears to have changed the traditional criteria for popular legitimacy (Welch 2002, using New Zealand and Australian illustrations). If there is a cultural problem, as suggested above, there doesn't seem to be any change happening in local government to solve it. There could be something happening through central government attempts at 'whole-of-government' programming and participatory planning, but none of this indicates the rise of local institutions that could be expected to take initiatives in a climate of relative autonomy. In New Zealand, engagement and partnership have recently illuminated the continuing problems of local government legitimacy and implicitly support arguments for stronger regional governance (Scott and McNeill 2006). There is no institutional basis for such change in Australia. Just as the revivalists seek cultural change towards entrepreneurialism and have apparently found a platform for it in some towns, so we might consider the existence of a platform for more political cultural change towards the legitimisation of regionalism.

\section{A culture of political subservience?}

Given the enthusiasm with which the new entrepreneurialism of the revivalists has been accepted in some communities, what has become of country-mindedness? Looking at the National Party, one might think it has faded at least a bit. The National Party, however, is still a country party and it retains its country-mindedness, with indications of agrarianism (as with its recent support for the 'single-desk' wheat exporter). The National Farmers Federation (NFF) continues to represent rural industry, though it is an industry organisation with only weak connections to rural communities and cannot be said to have 
been driven by agrarianism (Connors 1996) to the extent that the National Party has. Nevertheless, both organisations represent the rural interest, to the extent that there is a singular rural interest, though particularly the NFF is industry rather than community focused. Their level of political activity and activism contrasts with the passivity of the communities discussed above.

This could reflect the view that what is good for industry is good for the community. Giving priority to farmer interests has been noted in regional local politics (Gray 1991). When we consider the strength of activism, however, and the high level of political organisation among farmers, it is surprising that there has been so little activity at the local community level for the sake of local community interests. The reason for this paradox might lie in the rigidity of the state administrative apparatus and the low status of local government. In some circumstances, rural organisations seem very keen and able to take over government activities. In other circumstances, there seems to be no recognition of the possibilities. Some examples will illustrate this problem by way of contrasting the processes of privatisation in which opportunities have arisen for rural industries and communities.

\section{Grain handling}

The privatisation of grain handling in New South Wales was taken on by a farmer organisation as a great entrepreneurial opportunity and the capture of a government function to which farmers had been subservient. The Grain Handling Authority, previously known as the Grain Elevators Board, was sold in its corporatised form, the NSW Grain Corporation, by the Prime Wheat Association in 1992. In 2000, it merged with its Victorian counterpart. It merged with Queensland-based Grainco in 2003. In a letter to the Leader of the NSW Opposition, the Prime Wheat Association states:

We appreciate the support of your Party in our objective to acquire NSW Grain Corporation Ltd on behalf of the growers of NSW. It is essential that the privatisation of GrainCorp results in ownership by the users of the system as a natural and logical extension of their production process.

The letter goes on to state that the association has 8000 grower members and has been in existence since 1958. It concludes by saying: 'Your policy of growers acquiring ownership of GrainCorp as expressed by Mr Jack Hallam, Shadow Minister for Agriculture, Rural Affairs and Forests receives our strong endorsement' (Parliament of New South Wales 1992).

Elias (2005) reports that only 22 per cent of Graincorp shares are in the hands of farmers, but this does not alter the apparent enthusiasm and competence of a farmer organisation through acquiring not just a business, but a government function, which had been managed from Sydney since 1917. Farmers, at least for a time, placed themselves much further towards the entrepreneurial 
autonomous ends of the economic and political dimensions of their relationship with metropolitan Australia.

\section{Irrigation}

The recent history of irrigation is more complex, and differs among the states and within states. Unlike Victoria, New South Wales privatised its water distribution agency at the community level during the 1990s. The farmers were, according to parliamentary statements, keen to take over the provision of irrigation water at the local or regional level. 'The irrigators are eager to be handed the task of privatisation' (Member for Murray, in Parliament of New South Wales 1993). An interesting example of community involvement in the process is that of Coleambally Irrigation Co-Operative Limited (CICL), which took over from what was once the NSW Water Conservation and Irrigation Commission (from 1976, the Water Resources Commission) in 2000. All 373 of the cooperative's customers are also members (Meyer 2005:116). In the same year that the cooperative was corporatised (1997), the future membership was facing uncertainties of water supply and pricing as the state government discussed capping the quantities of water that could be diverted, issues that had been on the political agenda for several years (Parliament of New South Wales 1997). Water conservation measures were required of the privatised entities and were funded by the NSW Government (with respect to Murray Irrigation Limited, see Meyer 2005:105). In drought conditions, however, on top of environmental concerns and infrastructure problems, the management of water provision has been difficult.

This is especially so for locally or regionally based organisations that are required to manage state policy. It is reasonable to ask about the extent to which local people, including cooperative members, are able to interpret and act on their own interests. Just what privatisation and localisation/regionalisation have meant to farmers and other local people should be questioned. An anecdote of potential interest has been provided by an anthropologist working among irrigation farmers in an area managed by a cooperative (A. Brown, personal communication). In conversations about water and its management during some research on the values and interests of irrigation farmers, a privatised irrigation organisation was consistently referred to as 'the commission', being a reference to the Water Resources Commission, which had ceased to exist in 1986. 'The commission' was seen to have been an authoritarian, almost foreign, organisation. It did, as the privatised entities must still do, police the use of water. This raises the possibility that after the irrigation provider has been transferred to local ownership, though not entirely local control, it is seen to remain unchanged. It is reasonable to propose that the idea of local control is foreign to the irrigation farmer's world view. While grain handling indicates the legitimacy of the regionalisation of industry functions and the ease with which the ideas of privatisation and farmer 
control fit into the rural world view, government functions might not be so easily reconceptualised in regionalist terms.

\section{Natural resource management}

Among the rural functions of government, natural resource management (NRM) has become the most regionalised. Before discussing the process, it is worth differentiating regionalisation from regionalism. The latter refers to the idea, held among regional people, that regional-level administration is preferable to central administration. In the rural context, it is consistent with country-mindedness, though it has no necessary agrarian element. Regionalisation refers to the actions of central governments when they devolve responsibility, with or without significant authority, to sub-state organisations. The Commonwealth Government, with the cooperation of the states, has been responsible for regionalising NRM since the national Landcare program was established on a localised basis from 1988, but more significantly since the National Action Plan for Salinity and the Natural Heritage Trust provided substantial funding to organisations established on a regional basis (Moore and Rockloff 2006). It is hard, however, to see much regionalism in these changes. They have been instituted and delivered by central, state and the Commonwealth governments in terms laid down by those governments.

Regional NRM organisations, typically known as catchment management authorities (CMAs), have considerable power and resources. Although their constitutions vary among the states, they are not, however, particularly democratic. The CMA boards are often appointed rather than elected and central government is seen to maintain control. In Moore and Rockloff's (2006:268) research, the idea that a local government's elected representatives might participate was rejected by NRM group members interviewed on the grounds that local government was too parochial, despite local government being more democratic and accountable to its constituents.

These organisations have a very shaky status on the political dimension of regional-metropolitan, local-central relations. Despite having resources, they do not have regionalist origins and are very much creatures of state governments, although Moore and Rockloff see some opportunities for the exertion of regional agency. They conclude that the challenge of democratised NRM is that of transforming local government to suit effective regional delivery and democratic accountability, something that is apparently absent from at least some regional participants in CMAs.

\section{Railways ${ }^{1}$}

The examples above indicate the limitations of regional autonomy after some of the major changes of the past 20 years in the context of neo-liberalisation of 
rural, industrial and environmental policies. They show that although an entrepreneurial spirit has existed among farmers and others as members of industry organisations, and can be stimulated by central government activity at the local level, and although the interests of rural and metropolitan people and institutions have been and continue to be counterpoised in the tradition of country-mindedness, there seems to be limited readiness to become involved in ways that, in the context of 'new localism' and potentially 'new regionalism', could drive substantial change.

While it is problematic to explain the absence of a phenomenon, particularly when it is basically ideological, I propose that the problem could be due to the embedded nature of the rural world view in a tradition of administrative dependency and a reluctance to break away from that tradition. We have seen that reluctance, possibly in terms of the failure of Graincorp to maintain farmer ownership, but more evidently in the hint of a culture of subservience to the old irrigation provider and the rejection of local government as a vehicle for regionalisation.

A historical explanation for this non-phenomenon is offered by the history of the railways. More than any other institution, the railways, with some variation among the states, present the history of administrative dependency. This is partly because they were a very significant institution in rural development economically and culturally. Blainey (1968) sees the steam locomotive as so significant to the history of rural Australia and particularly the National Party that he suggests that a steam locomotive rather than a sheaf of wheat should be the centrepiece of its coat of arms, were it to have one. The railways established the pattern of rural settlement. While doing so, they focused the economy of each state, to slightly varying degrees, on the capitals. The railways were planned and administered from the colonial capitals in ways that ensured that metropolitan interests were furthered and alternative ports did not develop sufficiently to compete, or develop at all. Among transport historians, Lee (2003) makes this point about centralisation, though he does note variation among the colonies, later the states.

New South Wales and Victoria developed railway systems that focused the exportation of primary products on the colonial capitals and a few other ports, such as Newcastle in New South Wales and Geelong in Victoria. The more decentralised Queensland pattern is a consequence of the great distance between Brisbane, the capital, and the important northern port of Townsville, rather than any decentralising design by the colonial government. The other states' railway systems were centralised to varying degrees, with Western Australia being the most like Queensland due to its possession of a long coastline and a small number of widely separated ports. The idea of creating more ports in the centralised states was floated. For example, in 1911, a Royal Commission recommended to 
the NSW Government that a port be developed north of Newcastle and another south of Sydney, with systems of railway lines to serve them, in order to effect decentralisation (Gunn 1989). No such development occurred, though inland extensions of the system connecting Sydney continued into the 1930s. The Commonwealth Government has worked with the states on the interstate railway system, but has left the regional lines entirely to the states.

The railways enabled the creation of a rural society consistent with the image valued by an urban mercantile class rather than that valued by the rural aristocracy. Railway development was part of a deliberate program of social change, by way of the creation of a yeoman farmer class, conducted amid conflict between the 'squatters' and urban dwellers dominated by commercial interests. Change was fuelled by an ideology of civilisation. The railway would bring law and order and the institutions of religion and education to the inland. The railway was seen as one of 'the rudiments of bourgeois civilisation': a means to 'tether the mighty bush to the world' (Clark 1978:96). After noting how appreciative local populations were to the railway service, Gammage (1986:217) puts it bluntly: 'But the railways were built to serve men in Sydney who equated progress with the economic advancement of the metropolis.'

Gammage (1986:219) illustrates the subservience of a small town to the Sydney railway authorities: 'railway people, including railway workers, were convinced that some Narrandera street trees had been accidentally poisoned from a railway drain, but in 1983 the men in Sydney decided that this was not the case, and the [local government] council was obliged to let the matter drop'. Even local construction works were contracted to Sydney builders (Sharp 1998). Rural people have been well aware of their place in the relationship between rural interests and railway administrations.

Corresponding with the rise of road transport since the 1950s, the railway systems have come to be defined politically as problems more than as assets. Regional railways have been seen as problems almost from their opening. In New South Wales during the 1960s, the railways' finances rather than their capacity to provide transportation became a serious political problem, despite the railways still being able to cover operating expenses into the 1970s and freight services doing so into the 1990s (Industry Commission 1991). Nevertheless, the solution adopted by all governments except that of Queensland has been to privatise freight services and, in some instances, passenger services as well. In each case, buyers willing to continue regional services, for at least some period, were found.

While this change has been going on, the practice of 'cost shifting' has worsened. Cost shifting occurs when a regional railway is abandoned without any compensation to local government for the increased damage to be suffered consequently by local roads. The additional road maintenance costs can be substantial, which when accompanied by local concerns about road safety, gives 
local government an interest in rail transport. Such is the weakness of the still highly dispersed local government system that it has been unable to counter the problem. Many councils have protested to state governments about the deterioration of services and appealed for them to be improved, or in some cases restored, after cessation. At least one council has considered taking over a railway (Bourke Shire in 1989; see Industry Commission 1991). It was not successful. There has been no organisational platform and not much indication of enthusiasm among rural people for running their own railway system - certainly nothing comparable with the levels of enthusiasm and organisation shown by farmers through the privatisation of grain handling and irrigation. This differs substantially from the experience in North America, where there are now many locally and regionally operated railways, which are products of local initiative (Beingessner 2003). It should not be attributed to a lack of enthusiasm on the part of rural people or to a lack of entrepreneurialism or to the absence of the idea (see Lander and Smith 2004). Rather, sense can be made of it in terms of the centralised administrative tradition maintained by government and the contradictory nature of the relationship between railways and local communities.

\section{Conclusion: some research directions}

In concluding her discussion about potential applications of anthropology to regional development, Eversole (2005) points to the potential that the 'insider's perspective' has to illuminate and explain some of the problems faced by people seeking to develop Australia's non-metropolitan regions. She advocates application of ethnographic methods to interpret the 'ways of doing things' of regional people. In this chapter, I have explored some recent literature on local-central, or regional-metropolitan, relations in the context of the processes of neo-liberalisation and restructuring. I have attempted to refine current conceptualisation of economic dependency and political subservience. Consideration of these two elements as separate dimensions, alongside the problems of restructuring, provides a more penetrating analysis of the condition of rural communities, particularly potentially those not doing well: those most likely to be subject to the exhortations of the revivalists.

Having separated the economic from the political, for present analytical purposes at least, attention is turned to the political dimension. For present purposes and in the context of Australian history, this means state government administration and its relationship with local institutions, particularly local government. We find that centralism at the state level has been a profound element in this continuing relationship. When looking at some examples of privatisation into rural hands, we see faltering change towards devolution. Most importantly, we see a hint of evidence that rural cultural tradition does not easily accept devolution and probably lacks the resources to manage it to advantage. When we look at what might be or become significant devolution in the NRM context, 
we see no evidence of regionalism of a kind that seeks genuine devolution. This does not indicate an absence of regionalism but rather an application of a kind of regionalisation from the state that does not facilitate devolution. When we look at the history of the railways, we see an administrative institution that has cemented centralisation, in New South Wales at least, and very little evidence of regionalist thinking about transport problems.

Where to for anthropology? There are obviously some propositions here that ethnography could help to test. Even if the propositions are ultimately seen to fall over, exploration and interpretation of relations between rural people and the institutions of the state hold some promise for those, such as Herbert-Cheshire and Moore and Rockloff, who are concerned with regional sustainability and good governance. It is probably no coincidence that it is the traditionally well-organised farmers who have responded to regionalisation, even if they have neither seized nor maintained control. What of the other members of rural communities? What of their relations with farmers? What of relations between local government, its constituents and the states? All three of these questions have been tackled in the past. It might now be time to tackle them ethnographically again to build a platform for equitable and sustainable models of regional governance.

\section{Acknowledgment}

The gathering of material for this chapter was assisted by 'Towards Sustainable Regional Institutions', Discovery Project DP0556168, funded by the Australian Research Council.

\section{Bibliography}

Aitkin, D. 1985, 'Countrymindedness: the spread of an idea', Australian Cultural History, vol. 4, pp. 34-41.

Beingessner, P. 2003, 'Saskatchewan short line rails', in H. P. Diaz, J. Jaffe and R. Stirling, Farm Communities at the Crossroads, Canadian Plains Research Center, University of Regina, Regina, pp. 191-203.

Blainey, G. 1968, The Tyranny of Distance: How distance shaped Australia's history, Macmillan, London.

Bonney, N. 2004, 'Local democracy renewed?', Political Quarterly, vol. 75, no. 1, pp. 43-51.

Brown, A. J., Gray, I. and Giorgas, D. 2006, 'Towards a more regional federalism: rural and urban attitudes to institutions, governance and reform in Australia', Rural Society, vol. 18, no. 2, pp. 283-301.

Chapman, R. J. K. and Wood, M. 1984, Australian Local Government: The federal dimension, George Allen and Unwin, Sydney. 
Clark, C. M. H. 1978, A History of Australia. Volume IV: The earth abideth forever, 1851-1888, Melbourne University Press, Melbourne.

Cocklin, C. and Dibden, J. (eds) 2005, Sustainability and Change in Rural Australia, UNSW Press, Sydney.

Connors, T. 1996, To Speak With One Voice: The quest by Australian farmers for federal unity, National Farmers Federation, Canberra.

Costar, B. and Woodward, D. 1985, 'Conclusion', in B. Costar and D. Woodward, Country to National: Australian rural politics and beyond, George Allen and Unwin, Sydney, pp. 135-8.

Curry, J. M. 2000, 'Community worldview and rural systems: a study of five communities in Iowa', Annals of the Association of American Geographers, vol. 90, no. 4, pp. 693-712.

Dollery, B. and Crase, L. 2006, 'Optimal approaches to structural reform in regional and rural local governance: the Australian experience', Local Government Studies, vol. 32, no. 4, pp. 447-64.

Elias, D. 2005, 'Victoria unshackled: the good and bad', Age, 13 August 2005.

Eversole, R. 2005, 'The insider's perspective on regional development: using the anthropological perspective', in R. Eversole and J. Martin (eds), Participation and Governance in Regional Development, Ashgate, Aldershot, pp. 1-53.

Gammage, B. 1986, Narrandera Shire, Narrandera Shire Council, Narrandera.

Gray, I. 1991, Politics in Place, Social Power Relations in an Australian Country Town, Cambridge University Press, Cambridge.

Gray, I. 2005a, What can railway organisations learn from railway cultural traditions?, Paper presented at the National Railway Heritage Conference, Tamworth, 28-30 September 2005.

Gray, I. 2005b, 'Challenges to individual and collective action', in C. Cocklin and J. Dibden (eds), Sustainability and Change in Rural Australia, UNSW Press, Sydney, pp. 230-46.

Gray, I. 2006a, The centralisation of regional land transport in Australia and some of its consequences, Paper presented at the annual conference of the International Society for the Study of Transport, Traffic and Mobility, Paris, September.

Gray, I. 2006b, Transport and regionalism, Paper presented to the Australian Political Studies Association Conference, Newcastle, September.

Gray, I. and Lawrence, G. 2001, A Future for Regional Australia: Escaping global misfortune, Cambridge University Press, Cambridge. 
Gunn, J. 1989, Along Parallel Lines, Melbourne University Press, Melbourne.

Herbert-Cheshire, L. 2003, 'Translating policy: power and action in Australia's country towns', Sociologia Ruralis, vol. 43, no. 4, pp. 454-73.

Herbert-Cheshire, L. and Higgins, V. 2004, 'From risky to responsible: expert knowledge and the governing of community-led rural development', Journal of Rural Studies, vol. 20, no. 3, pp. 289-302.

Hinshelwood, E. 2001, 'Power to the people: community-led wind energy - obstacles and opportunities in a South Wales valley', Community Development Journal, vol. 36, no. 2, pp. 95-110.

Industry Commission 1991, Rail Transport. Volume I: Report, Australian Government Publishing Service, Canberra.

Kenyon, P. and Black, A. (eds) 2001, Small Town Renewal: Overview and case studies, Rural Industries Research and Development Corporation, Canberra.

Lander, F. and Smith, G. 2004, 'NSW branch lines: has the time come for the Australian short line revolution?', Railway Digest, vol. 42, no. 1, pp. 26-8.

Lee, R. 2003, 'The railway age, 1874-1920', Linking A Nation: Australia's transport and communications, 1788-1970, Australian Heritage Commission, Canberra, viewed 30 November 2006, <http://www.ahc.gov.au/publications/national-stories/transport/>

Meyer, W. 2005, The irrigation industry in the Murray and Murrumbidgee Basins, Technical Report No. 03/05, Cooperative Research Centre for Irrigation Futures.

Moore, S. and Rockloff, S. F. 2006, 'Organizing regionally for natural resource management in Australia: reflections on agency and government', Journal of Environmental Policy and Planning, vol. 8, no. 3, pp. 259-77.

Murray Irrigation Limited 2006, MIL Infrastructure, $<$ http://www.murrayirrigation.com.au/content.aspx?p=20051>

O'Toole, K. and Burdess, N. 2004, 'New community governance in small rural towns: the Australian experience', Journal of Rural Studies, vol. 20, no. 4, pp. 433-43.

Parliament of New South Wales 1992, 'NSW Grain Corporation Holdings Limited Bill', Hansard, 6 May 1992, viewed 25 May 2007, $<$ http://www.parliament.nsw.gov.au/prod/parlment/HansArt.nsf/V3Key/ LA19920506023>

Parliament of New South Wales 1993, 'Irrigation Scheme Privatisation', Hansard, 20 May 1993, viewed 25 May 2007, 
$<$ http://www.parliament.nsw.gov.au/prod/PARLMENT/hansArt.nsf/V3Key/ LA19930520041>

Parliament of New South Wales 1997, 'Minister for Land and Water

Conservation', Hansard, 8 April 1997, viewed 25 May 2007, $<$ http://www.parliament.nsw.gov.au/prod/parlment/hansart.nsf/V3Key/ LA19970408048>

Pini, B. 2006, 'A critique of "new" rural local governance: the case of gender in a rural Australian setting', Journal of Rural Studies, vol. 22, no. 4, pp. $396-408$.

Scott, C. and McNeill, J. 2006, Community strategic planning and the pursuit of whole of government outcomes, Paper presented at Governments and Communities in Partnership: From theory to practice, University of Melbourne, 25-27 September 2006.

Sharp, S. A. 1998, Destined to fail: management of the New South Wales railways 1877-1995, Unpublished PhD thesis, University of Sydney.

Soorley, J. 2004, 'Do we need a federal system? The case for abolishing state governments', in W. Hudson and A. J. Brown (eds), Restructuring Australia: Regionalism, republicanism and reform of the nation-state, Federation Press, Sydney, pp. 38-46.

Stoeckel, A. 1998, 'Farmers can solve their problems by themselves', Australian Farm Journal, vol. 8, no. 9, pp. 16-17.

Stoker, G. 2004, 'New localism, progressive politics and democracy', Political Quarterly, vol. 75, no. s1, pp. 117-29.

Transport and Population Data Centre 2004, New South Wales State and Regional Population Projection, 2001-2051, 2004 Release, Department of Infrastructure, Planning and Natural Resources, Sydney.

Vanclay, F., Mesiti, L. and Howden, P. 1998, 'Styles of farming and farming subcultures: appropriate concepts for Australian rural sociology?', Rural Society, vol. 8, no. 2, pp. 85-107.

Welch, R. 2002, 'Legitimacy of rural local government in the new governance environment', Journal of Rural Studies, vol. 18, no. 4, pp. 443-59.

\section{Endnotes}

\footnotetext{
${ }^{1}$ Parts of this section draw on material in Gray (2006a, 2006b).
} 